\title{
THE PECULIARITIES OF OPENING THE REHABILITATION PROCESS IN THE CONTEXT OF GEORGIAN AND JAPANESE LAW
}

\author{
Sesili Kadaria \\ Guest Lecturer, \\ Georgian National University SEU
}

\begin{abstract}
The article "Peculiarities of opening the Rehabilitation Process in the context of Georgian and Japanese Law" discusses the beginning of the rehabilitation process by a legal-comparative method, Georgian legislative novelty, and vague norms that need to be refined in the Georgian reality. Effective insolvency legislation is a key tool for maintaining economic stability, the government also has an important role and responsibility to create a legal framework that will help maintain the viability of the enterprise in times of financial difficulties.

It is clear that during the elaboration of the new law of Georgia "On Rehabilitation and Collective Satisfaction of Creditors" (enacted on April 1, 2021), significant research was carried out by the group. "Legislative Guide to Insolvency Law" by the UN Commission on International Trade Law (UNCITRAL) was studied, as well as International Principles on "Effective Insolvency and Protection of Debtor and Creditor Rights" developed by the World Bank. The new law clearly outlined the role of rehabilitation as a target and named the debtor's rehabilitation as the country's priority. Moreover, its purpose is to encourage timely appeal to the court. The enactment of the law has eliminated the shortcomings that, in many cases, significantly delay the process.

It should be noted that a lot of attention was paid to Japanese law during the drafting of the bill, as according to the World Bank, it is in the top three countries in Insolvency Law. Based on the court rulings, the article presents the obstacles to the rehabilitation process in theoretical and practical terms, discusses the vague norms of the new legislation of Georgia, and offers modern visions of regulation.
\end{abstract}

Keywords: „Civil RP“, “SLP”, "BP”, “RL”, regulated agreement, conversion, and more.

\section{Introduction}

In a democratic country, the economic core is based on the enterprises, whose function is not only to strengthen the social level but also to significantly increase the country's economic indicator. In order to ensure public welfare and stable economic turnover, the country aims to introduce mechanisms to support the enterprise which ensures their recovery from the financial crisis. The rehabilitation institute in modern law is gradually becoming more powerful. It is an auxiliary mechanism for the survival of the enterprise, and its effective management largely depends on the legislation. The timely start of the rehabilitation process will enable the legal entity to overcome the financial difficulties, move forward, and strengthen them. This is the reason for the beginning of the rehabilitation process, the main subject of which is the rehabilitation manager.

In 2015, at the request of the Ministry of Justice, the Georgian Insolvency System was assessed by the United States Agency for International Development (USAID) project "Governance for Development". According to the research, "Law of Georgia on Insolvency Proceedings" was not used for opening rehabilitation process, it was obvious, that only 10 court hearings were held and most of them ended with the bankruptcy of the debtors. The circle of eligible subjects was considered to be an obstacle to the rehabilitation process, this has changed in the current situation.

On April 1, 2021, the Law of Georgia on Rehabilitation and Collective Satisfaction of Creditors came into force, which changed the approach of the state to the process of insolvency and named the rehabilitation of the 
enterprise as a priority. However, the focus should not be on rescuing the debtor alone. It is important that the purpose of rehabilitation is to satisfy creditors by rescuing the debtor and not just to rescue the debtor without taking into account the interests of the creditors. ${ }^{66}$

The article discusses the start of the rehabilitation process regulated by the new law of Georgia, discusses the Japanese insolvency law by a legal-comparative method, which clearly presents the problems of enforcement in practice, and also will help the Georgian legislator to develop the rehabilitation process.

Why Japan? In the framework of World Bank's project "Do Business", Japan was able to take the lead in Insolvency Law, it ranks as $3^{\text {rd }}$ in the world and its rehabilitation act is the best fit for the needs of the enterprise. Moreover, Japanese insolvency law governs bankruptcy and rehabilitation through independent acts. The "Civil Rehabilitation Act" discussed in the article clearly outlines the effective mechanism of rehabilitation.

The article discusses the ambiguity of the legal basis for initiating rehabilitation and suggests mechanisms for resolving problematic issues for the legislature. Is there enough intervention to start the rehabilitation process and what happens if the rehabilitation plan is not approved?! Discussing these and other issues, to my opinion, will enable practicing lawyers, judges, companies and the rehabilitation manager to directly see the problems of opening the rehabilitation process, the proposed legal innovation and their compliance with the recognized standards.

\section{The model of insolvency law in Japan}

In Japan, legal proceedings for companies with financial difficulties are divided as follows: 1. The rehabilitation process, which in turn consists of A) Civil Rehabilitation proceedings and B) corporate reorganization proceedings; 2 . The liquidation process which consists of A) bankruptcy proceedings and B) special liquidation proceedings.

The Civil Rehabilitation Act offers two alternative ways for a company to survive, first is the well-known scheme, Civil Rehabilitation Proceedings (so-called "Civil RP"), which are the procedures owned by the debtor, to meet the debtors needs through a rehabilitation plan

approved by the creditors' meeting and ensure the financial progress of the enterprise. The second important innovation is the corporate reorganization procedure, which differs from standard reorganization (hereinafter referred to as "RP"). Only stock/currency companies use these rehabilitation procedures, their main goal is to get rid of the company structures which only brings losses. Actually, by transferring the assets a new structure is created, with a clean past and financial prospect. The RL also ensures the protection of the creditor's certain rights. One of such defenses is administrative lawsuits and claims for the debtor's staff salaries, fees for the reorganization trustee, and the expenses incurred after the approval of the reorganizational plan.

You can pay for those requests at any time and without the reorganizational plan and it's completely different from the reorganizational claims which allow secured and unsecured creditors to conduct administrative proceedings only under the RL plan. ${ }^{67}$

Japanese law regulates bankruptcy proceedings as a separate act (so-called "BP"): Liquidation proceedings appointed by a court bankruptcy trustee are mainly formal in nature, the creditors' claims are fairly executed, and all assets owned by the company are sold in good faith. The Bankruptcy Act regulates special liquidation procedures ("SLP"); which deal with the liquidation of the stock company directly through the directors. The

\footnotetext{
${ }^{66}$ K. Meskhishvili "Rehabilitation deficiencies in accordance with the Law of Georgia on Insolvency Proceedings of 2007" 204", "Fundamentals of Insolvency Proceedings in accordance with the Law of Georgia on Rehabilitation and Collective Satisfaction of Creditors "(C) GIZ, 2021 Electronic version of the publication can be found at: lawlibrary.info/ge P. 112.

${ }^{67}$ Global Restructuring \& Insolvency Guide, Baker McKenzie, <http://restructuring.bakermckenzie.com/wpcontent/uploads/sites/23/2017/01/Global-Restructuring-Insolvency-Guide-New-Logo-Japan.pdf> pg. 3 [L.s. 13.05.2021].
} 
directors of the company are its liquidators and they distribute the assets according to the agreement unless it is established otherwise by the charter or the shareholder's meeting. ${ }^{68}$

The rehabilitation manager is revealed directly during the rehabilitation process, his functions are stated in the "Civil Rehabilitation Act", therefore, the chapters below will be devoted to only its study. In order to visualize the manager's activities, it is interesting to consider what process he is involved in and what criteria the legislator offers to the enterprise entities.

\section{The opening of the rehabilitation process (Japanese model)}

\subsection{Filing a petition}

Article 21 of the Japanese "Civil Rehabilitation Act" regulates the basis for initiating the rehabilitation process. According to part 1 of article 21, when there exists actual indisputable circumstance, that it is possible to initiate bankruptcy proceedings against the debtor, the debtor can file a motion to initiate a rehabilitation case in court. This is a case when the debtor is unable to pay his debts without significant disruption to the development of the business. ${ }^{69}$ On this ground, the creditors themselves can also apply to the court.

The types of creditors are not limited by the law, among them, even unsecured creditors are able to request the opening of the rehabilitation cases. The issue stated above emphasizes the simplicity of starting a rehabilitation procedure and flexible legislation.

When filing a reopening case for the rehabilitation process, the court usually issues a temporary injunction to prevent the debtor from making payments ${ }^{70}$ In case there is an additional need, the court issues individual enforcement paper which includes the prohibition of sales, putting a mortgage on the debtor's property, suspension of enforcement, etc. against a rehabilitation claim, and if there are special circumstances, it will issue a complete ban suspending the claims and enforcement against all rehabilitation creditors. ${ }^{71}$

As mentioned above, the court will grant the motion if (1) there is a risk that the debtor will not be able to pay his debt, the debtor's liabilities exceed his assets, or (2) the debtor is unable to repay the already overdue debts so as not to pose a significant risk to the development of the business.

However, the motion will not be granted if the court will determine that the debtor is unlikely to prepare a rehabilitation plan, the mentioned plan has not been approved by the creditors, or there is a chance that the court will not approve it. The order for opening rehabilitation is usually issued within one week of filing. In addition, before issuing an order, the debtor usually holds an explanatory meeting with the creditors in order to explain how and why the motion and the content of civil rehabilitation proceedings were filed in court. ${ }^{72}$

\subsection{The approval of the rehabilitation plan}

According to article 165, part 1 of the Civil Rehabilitation Act, after the inspection of the evidence in court, the rehabilitation debtor is obliged to prepare the proposed rehabilitation plan and introduce it to the court. ${ }^{73}$

\footnotetext{
68 Published and reproduced with kind permission by Global Legal Group Ltd, London, ICLG TO: CORPORATE RECOVERY \& INSOLVENCY 2017, pg.126https://www.nishimura.com/sites/default/files/tractate_pdf/en/47077.pdf [L.s.5.05.2021].

${ }^{69}$ Japan Civil Rehabilitation Act, Act No. 225 of December 22, 1999. Article 21.

${ }^{70}$ Ibid Article 30.

${ }^{71}$ A. Lizuka. "RESTRUCTURING SYSTEMS AND PROCEDURES IN JAPAN" International Insolvency Institute, TMI Associates Tokyo, 2016, p.5.

${ }^{72}$ SH. Miyazaki., SH. Fukuoka., Y. Yukawa., "An introduction to court procedures for insolvency in Japan”, Nishimura \& Asahi, 4/8/2011. P.4.

${ }^{73}$ Japan Civil Rehabilitation Act, Act No. 225 of December 22, 1999. Article 165.
} 
The debtor prepares the civil rehabilitation plan, which provides the protection of the unsecured creditor's rights, the amount of payment, payment period, etc, whereas unsecured creditors determine whether to approve the proposed plan at the creditors' meeting. The rehabilitation plan will be approved if it will receive (1) the consent from the majority of voting creditors present at the creditor's meeting (including those who have voted in advance by filling out the required form) and (2) the consent from creditors who have the right to vote, which is not less than half of the total amount of the votes, and will take effect if the court approves the plan. After this process, the debtor reimburses the debt according to the plan and is released from the remaining debts. ${ }^{74}$

The court proceedings reveal that before approving the rehabilitation plan in court, the debtor must obtain the consent of the voting creditors, otherwise the court has the leverage not to approve the rehabilitation plan and a number of expenses that are connected with the opening procedure, those will be imposed on the debtor again.

It is interesting what happens if the creditors do not approve the rehabilitation plan?

In this case, if certain requirements are met, the court may convene the meeting of the creditors again and give the debtor/trustee the consent of the creditors. However, when the creditors finally reject the rehabilitation plan, the court will issue an order to terminate the civil rehabilitation case and these restructuring procedures are transferred to bankruptcy proceedings. Even after filing for bankruptcy, according to a court order in a civil rehabilitation or corporate reorganization case, administrative expenses that occurred based on the mentioned litigation will be paid in favor of other claims in the bankruptcy case. ${ }^{75}$

\subsection{The Court order for opening the rehabilitation regime}

Within one week from the date of filing a motion for civil rehabilitation, the court shall decide whether to open the rehabilitation process or to reject the motion.

Subsequently, the motion to initiate a civil rehabilitation case will not be granted if the court decides that, (Article 25, Civil Rehabilitation Act): A) The expenses of civil rehabilitation procedures are not prepaid. B) Bankruptcy proceedings or special liquidation cases are pending before the court and the enforcement of any case is in the common interest of the creditors. C) It is obvious that the preparation or approval of the proposed rehabilitation plan or even the confirmation of the plan probably is not possible. D) A petition for civil rehabilitation proceedings has been filed for an unjustified purpose or has not been compiled in good faith. ${ }^{76}$

The proposed rehabilitation plan will come into force after the court issues a final order granting the motion (Article 176, Civil Rehabilitation Act). ${ }^{77}$ The accountability of the debtor is only limited to the rehabilitation plan mentioned above, the operation of the disputes stops.

The debtor has a maximum of 3 years after the court's decision to fulfill his obligations according to the rehabilitation plan. Otherwise, its bankruptcy proceedings will be initiated.

In the interim conclusion, the following circumstance became clear with the Japanese model, the country's priority is the rehabilitation process. The debtor must exhaust all legal means to start rehabilitation and only then is he entitled to move to bankruptcy regime. The Civil Rehabilitation Act clearly shows that if there is a danger that the debtor will not be able to fulfill its overdue obligations, or its fulfillment will result in a large

\footnotetext{
${ }^{74}$ An Introduction to Court Procedures for Insolvency in Japan https://www.nishimura.com/en/articles/article_10073.html\#16>> [L.s. 6.04.2021].

${ }^{75}$ SH. Miyazaki., SH. Fukuoka., Y. Yukawa., "An introduction to court procedures for insolvency in Japan”, Nishimura \& Asahi, 4.8.2011. P.16.

${ }^{76}$ Reuters T. UK Practic law. $<$ https://uk.practicallaw.thomsonreuters.com/6-607

8886? _rTS $=20210212114558179 \&$ transitionType $=$ Default\&contextData $=($ sc.Default $) \&$ firstPage $=$ true \#co_anchor_a501485 $>$ [L.s. 16.06. 2021$]$.

${ }^{77}$ A. Lizuka "RESTRUCTURING SYSTEMS AND PROCEDURES IN JAPAN" International Insolvency Institute, TMI Associates Tokyo, 2016, p.11.
} 
financial loss to the enterprise, the debtor is obliged to start the rehabilitation process. The start of the rehabilitation process is largely related to the approval of the rehabilitation plan. Under the Japanese model, the debtor court begins negotiations with the creditors before the trial begins and, with their consent, submits the plan to the court for approval. But, what happens if the debtor fails to obtain the consent of the creditors, ultimately this is the basis for initiating the debtor bankruptcy regime. Let's see what procedures will be needed to start rehabilitation based on the example of Georgia.

\section{The rehabilitation process - Georgia's legislative innovation}

\subsection{General overview}

The law of Georgia on "Rehabilitation and collective satisfaction of creditors" revolutionized insolvency law, performed a complete reform that will in the long run change the economic picture of the country. It all stems from the purpose of the law, which says that "the purpose of this law is to collectively satisfy the demands of the creditors by achieving rehabilitation, and in case if the rehabilitation isn't possible to achieve - by distributing the funds received from the sale of the insolvency mass " ${ }^{78}$ The given regulation proves that the rehabilitation of the enterprise and the introduction of supporting mechanisms has become a priority for the country. However, it should be clarified that the greatest attention is paid to the interests of the creditors, whose satisfaction is ensured by the rehabilitation process.

The role of the government is to create such legislative mechanisms where we will see a balance between the interest of the enterprise and the creditor's rights. Therefore, it is crucial to correctly interpret the new normative act.

The stated law has simplified the commencement of insolvency proceedings by canceling the customs fee and the number of creditors' claims. In particular, if the amount of demand was limited in the previous legislation, e. g. to $50000 \mathrm{GEL}$, in case of 2 creditors to $1500000 \mathrm{GEL}$

and the enterprise was left with no choice but to go bankrupt, nowadays there is no such criterion.

The following have the right to file an insolvency application in court: A) Debtor - through a person authorized to manage and represent the enterprise; B) Creditor; C) The supervisor of the regulated agreement; D) Rehabilitation Manager - at the request of conversion, when the rehabilitation regime is open to the debtor; E) Liquidators - at the request of conversion when bankruptcy mode is open for the debtor. ${ }^{79}$

One of the most well-proven ways of effective rehabilitation is - debt management - when the existing management, which trustworthily carried out its activities, continues to manage and engages with supervisors in negotiations with creditors to successfully complete the rehabilitation regime. ${ }^{80}$

Most importantly, different cases of rehabilitation and bankruptcy were identified. In particular, insolvency proceedings may be executed: A) In rehabilitation mode; B) In bankruptcy mode. ${ }^{81}$ The authorized entity decides for himself which process to request.

\footnotetext{
${ }^{78}$ The law of Georgia on "Rehabilitation and collective satisfaction of creditors", Date of acceptance: 18.09.2020, article. 1.

79 The law of Georgia on "Rehabilitation and collective satisfaction of creditors", Date of acceptance: 18.09.2020, Source of publication, Date: Website, 25.09.2020, m. 43.

${ }^{80}$ K. Meskhishvili, "Rehabilitation Deficiencies on Insolvency Proceedings" by the Georgian Law of 204, the year 2007", "Fundamentals of Insolvency Proceedings on Rehabilitation and Collective Satisfaction of Lenders" by the Georgian Law, (C) GIZ, 2021 An electronic version of the publication can be found on the website lawlibrary.info/ge, page. 118.

${ }^{81}$ See footnote 13. article. 6 .
} 
According to the current legislation, the priority of the government - the rehabilitation process will have an important place in the enterprise's activities since the fiduciary obligation of the manager is to turn the enterprise into a profitable entity.

\subsection{Petition for opening the rehabilitation process and authorized entities (Georgian model)}

The law of Georgia on "Rehabilitation and collective satisfaction of creditors" establishes formal and material admissibility conditions for opening the rehabilitation process. The formal preconditions are set out in the A V subsection of the $1^{\text {st }}$ paragraph of Article 44, as for material or content admissibility, the debtor has to prove that he is an insolvent or expected insolvent entity and that by opening the rehabilitation regime there is a reasonable probability of achieving the goal of rehabilitation. ${ }^{82}$ The burden of alleging this issue falls on the debtor.

The law allows both the debtor and the creditors to open the rehabilitation process, but imposes other obligations on them for the purpose of opening the process. For example: If the insolvency application is filed by the debtor in court, a rehabilitation plan must be submitted, which in one case must be approved and signed by the creditors, and in the other case must be presented in a fully completed form. The rehabilitation plan is established by the debtor in cooperation with the supervisor, however, the rehabilitation plan needs approval from the creditors. The rehabilitation plan must be approved by the creditors within 6 months after the publication of the verdict on the start of the rehabilitation regime. The stated period may be extended by no more than 3 months by the decision of the creditors' meeting. After the expiration of this period, the court will decide to liquidate the debtor. ${ }^{83}$

The request of the creditor to open the rehabilitation regime must be substantiated by the legal interest as to why he wants to open the rehabilitation process. ${ }^{84}$ This legislative record makes it clear that the creditors' appeal to the court requesting the opening of the rehabilitation process will not be massive. For creditors, of course, it is more beneficial to meet their demands

in a short time more than a time-consuming process. Accordingly, the creditors' interest should be reflected in the rehabilitation plan.

The Law allows the possibility of rehabilitation regime to go into bankruptcy (conversion) if the rehabilitation plan has not been approved, or if the rehabilitation manager believes that there is no reasonable chance of achieving the rehabilitation goal. ${ }^{85}$ Request for transition from a bankruptcy regime to possible rehabilitation mode, in which case the bankruptcy trustee shall additionally submit the information to the court: A) Detailed information on the current bankruptcy process; B) The bankruptcy trustee's identification and contact information; C) A copy of the court's decision on the assignment of the bankruptcy trustee.

We have a legislative innovation on our hands, in particular, the supervisor of the regulated agreement has the possibility of applying to the court and requesting the opening of the rehabilitation regime. According to the law, he is required to submit a regulated agreement to the court. The stated directive is the example case of a failed agreement, in particular, if the parties, the debtor, and the creditors are unable to reach an agreement on their own, the supervisor of the regulated agreement has the right to apply to the court.

In case of unsuccessful fulfillment or achievement of the regulated agreement, it is unacceptable to leave the debtor in the management at the beginning of further rehabilitation. ${ }^{86}$

\footnotetext{
${ }^{82}$ See footnote 14. m. 44, subsection T of the $1^{\text {st }}$ Article.

${ }^{83}$ See Footnote, page. 120.

${ }^{84}$ See Footnote 13., subsection A of the $4^{\text {th }}$ Article.

${ }^{85}$ Explanatory note on "Rehabilitation and collective satisfaction of creditors", of Georgian law project, page 14-15.

${ }^{86}$ N. Amisulashvili. "Regulated Agreement" "Fundamentals of Insolvency Proceedings" on "Rehabilitation and Collective Satisfaction of Creditors" by the Georgian law, (C GIZ, 2021 An electronic version of the publication can be found on the website lawlibrary.info/ge, page. 176 .
} 


\subsection{The standard for substantiating a court decision}

The court checks the formal admissibility of the application and then decides to open a rehabilitation regime. If the received application has a defect, the court issues a verdict and gives the applicant 5 days to correct it.

It is interesting in which case does the court refuse to open a rehabilitation process?

This issue is covered by Article 48 of the Law, in particular, "if the court finds that the debtor is not insolvent or is expected to be insolvent it shall issue a rejection to admit an insolvency application" ${ }^{87}$ According to the given rule, we must see the qualification's criteria. Does the law include the definition of expected insolvency?

Paragraph 3 of Article 7 of the Law regulates the criterion of insolvency of the debtor, in particular, if the debtor has suspended the activity, or was entered in the debtors' register within 12 months before the application is submitted, or at least 30 days before filing a claim against the debtor, if the measure of securing the payment of the tax debt and other circumstances is valid, the debtor is considered insolvent. However, as for the notion of expected insolvency, "expected insolvency exists if there is an acceptable reason to believe that the debtor will become insolvent". ${ }^{88}$ The given regulation is general and gives the court wide discretion to qualify the debtor in individual cases as an insolvent debtor.

\section{Conclusion}

The paper has discussed the peculiarities of opening the rehabilitation process in the Japanese and Georgian legislative acts. Noticeably, there is a separate law in Japan "Civil Rehabilitation Act", which in detail discusses the grounds for opening or rejecting the process. It should be noted that according to the Japanese model, the approval of the rehabilitation plan is the basis for opening the rehabilitation process. If the plan is not approved by the creditors, it will trigger bankruptcy. In the interest of the creditors, the debtor will be able to start the rehabilitation process without any problems by negotiating before the trial.

As for our legislative innovation, the independent litigation of the opening of the rehabilitation process, the simplification of the circle of authorized subjects, the possibility of conversion, and many other issues underline the priority of the rehabilitation regime. The paper showed us that the court will have to substantiate the grounds for the refusal and their role will be still relevant. In case of refusal, the court should be guided by international standards and its decisions should be in line with recognized principles.

A comparison of the Japanese and Georgian legal systems has revealed their similarities in certain respects, in particular, the introduction of a rehabilitation plan is mandatory for lenders in both cases. The simplicity of opening the process and the possibility of leaving the debtor in management will lead to the relevancy of the insolvency field.

The issue discussed in the article will contribute to the refinement of Georgia's current legislation and the development of this field.

\footnotetext{
${ }^{87}$ See footnote $13,2^{\text {nd }}$ section of the Article m. 48 .

${ }^{88}$ See footnote $13,2^{\text {nd }}$ section of the Article m. 7.
} 


\section{Bibliography}

1. Global Restructuring \& Insolvency Guide, Baker Mckenzie, http://restructuring.bakermckenzie.com/wpcontent/uploads/sites/23/2017/01/Global-Restructuring-Insolvency-Guide-New-Logo-Japan.pdf [Last seen 31.05.2021];

2. Published and reproduced with kind permission by Global Legal Group Ltd, London, ICLG TO: CORPORATE RECOVERY \& INSOLVENCY 2017, https://www.nishimura.com/sites/default/files/tractate_pdf/en/47077.pdf [Last seen 5.31.2021];

3. Ataru Lizuka" RESTRUCTURING SYSTEMS AND PROCEDURES IN JAPAN" International Insolvency Institute, TMI Associates Tokyo, 2016;

4. Shintaro Miyazaki Shinnosuke FukuokaYusuke Yukawa., "An introduction to court procedures for insolvency in Japan", Nishimura \& Asahi, 4.8.2011;

5. Japan Civil Rehabilitation Act, Act No. 225 of December 22, 1999 https://www.nishimura.com/en/articles/article_10073.html\#16 [Last seen 6.04.2021];

6. Reuters TH. practice law https://uk.practicallaw.thomsonreuters.com/6-607 8886? $\operatorname{lrTS}=20210212114558179 \&$ transitionType=Default\&contextData=(sc.Default $) \&$ firstPage=true\#co_anchor_a5014 85 [Last seen 16.06.2021];

7. Ketevan Meskhishvili, "Rehabilitation Deficiencies on Insolvency Proceedings" by the Georgian Law of 204, the year 2007", "Fundamentals of Insolvency Proceedings on Rehabilitation and Collective Satisfaction of Lenders" by the Georgian Law, (C) GIZ, 2021 An electronic version of the publication can be found on the website lawlibrary.info/ge;

8. The law of Georgia on "Rehabilitation and collective satisfaction of creditors", Date of acceptance: 18.09.2020, Source of publication, Date: Website, 25.09.2020;

9. Explanatory note on "Rehabilitation and collective satisfaction of creditors", of Georgian law project;

10. Nana Amisulashvili "Regulated Agreement" "Fundamentals of Insolvency Proceedings" on "Rehabilitation and Collective Satisfaction of Creditors" by the Georgian law, (C GIZ, 2021 An electronic version of the publication can be found on the website lawlibrary.info/ge. 